\title{
Pengembangan Potensi Usaha Abon untuk Meningkatkan Daya Saing Produk di UMKM Ksatria Kelurahan Jagalan, Kecamatan Jebres, Surakarta
}

\author{
Adi Magna Patriadi Nuhriawangsa ${ }^{1}$, Lilik Kartikasari ${ }^{1}$, Agung Budiharjo ${ }^{2}$, Winny Swastike ${ }^{\text {* }}$ dan Bayu $^{\text {Agan }}$ \\ Setya Hertanto ${ }^{1}$ \\ ${ }^{1}$ Program Studi Peternakan, Fakultas Pertanian, Universitas Sebelas Maret, Surakarta, Indonesia; ${ }^{2}$ Program Studi \\ Biologi, Fakultas Matematika dan Ilmu Pengetahuan Alam, Universitas Sebelas Maret, Surakarta, Indonesia
}

Diterima: 23 Agustus 2020; Disetujui: 21 Oktober 2020

\begin{abstract}
Abstrak
Daya saing di Usaha Mikro, Kecil dan Menengah (UMKM) merupakan hal yang sangat penting untuk ditingkatkan. Hal tersebut disebabkan karena UMKM merupakan kekuatan dalam pendorong pembangunan ekonomi. Tujuan kegiatan ini adalah untuk meningkatkan daya saing produk UMKM Ksatria Kelurahan Jagalan, Kecamatan Jebres, Surakarta. Metode yang dipergunakan adalah pelatihan dan pendampingan. Hasil yang dicapai adalah meningkatnya pemahaman pelaku UMKM tentang pemasaran yang meliputi aspek: produk UMKM meliputi kualitas abon, kemasan abon dan label terkait informasi penting yang hendak disampaikan ke konsumen hingga tercapainya peningkatan keterampilan dan eksistensi UMKM. Faktor promosi pada pemasaran era digital, harga, pemasaran berbasis teknologi, branding, inovasi dan kreativitas serta daya saing produk. Capaian program sudah cukup memuaskan. Hal ini dapat dilihat dari capaian yang telah diperoleh. Perbaikan yang dilakukan pada kegiatan ini membuat mitra menghasilkan produk berdaya saing. Saran untuk kegiatan ini adalah pendampingan dapat dilakukan secara berkala dan disertai pengevaluasian di setiap kegiatan.
\end{abstract}

Kata kunci: abon; daya saing; UMKM

\section{Development of Abon Business Potential to Increase Product Competitiveness at SMEs Ksatria, Jagalan, Jebres Sub-district, Surakarta}

\begin{abstract}
Competitiveness in the competitiveness of Micro, Small and Medium Enterprises (MSMEs) is very important to be improved. This is because MSMEs are a force in driving economic development. The purpose of this activity is to improve the competitiveness of MSMEs products Ksatria Jagalan Village, Jebres Sub-district, Surakarta. The methods used are training and mentoring. The results achieved were an increase in the understanding of MSME, actors about marketing which includes aspects: MSME products including quality of product of abon, packaging of abon and labeling related to important information to be conveyed to consumers to increase the skills and existence of MSME. In addition, the factors of promotion of digital marketing era, price, technology-based marketing, branding, innovation and creativity, product competitiveness. The program's achievements are quite satisfactory. This can be seen from the achievements that
\end{abstract}

\footnotetext{
*Corresponding author: winny@ staff.uns.ac.id

Cite this as: Nuhriawangsa, A. M. P., Kartikasari, L., Budiharjo, A., Swastike, W., \& Hertanto, B. S. (2020). Pengembangan Potensi Usaha Abon untuk Meningkatkan Daya Saing Produk di UMKM Ksatria Kelurahan Jagalan, Kecamatan Jebres, Surakarta. AgriHealth: Journal of Agri-food, Nutrition and Public Health, 1(2), 103109. doi: http://dx.doi.org/10.20961/agrihealth.v1i2.43949
} 
have been obtained. The improvements made in this activity have made partners produce competitive products. The suggestion for this activity is that mentoring can be carried out continuously under mentoring and evaluation can be carried out periodically.

Keywords: abon; competitiveness; MSMEs

\section{PENDAHULUAN}

Usaha Mikro, Kecil dan Menengah (UMKM), merupakan salah satu kekuatan pendorong terdepan dalam pembangunan ekonomi (Bank Dunia, 2005). UMKM memegang peranan yang cukup signifikan dalam perekonomian. Berdasarkan Undang-Undang No. 20 Tahun 2008 tentang UMKM mendefinisikan UMKM berdasar kriteria tertentu, antara lain sebagai berikut: (a) usaha mikro adalah usaha produktif milik orang perorangan dan atau badan usaha perorangan yang memenuhi kriteria usaha mikro sebagaimana diatur dalam undang-undang ini; (b) usaha kecil adalah usaha ekonomi produktif yang berdiri sendiri yang dilakukan oleh orang perorangan atau badan usaha yang bukan merupakan anak perusahaan atau bukan cabang perusahaan yang dimiliki, dikuasai atau menjadi bagian baik langsung maupun tidak langsung dari usaha menengah atau usaha besar yang memenuhi kriteria usaha kecil; (c) usaha menengah adalah usaha ekonomi produktif yang berdiri sendiri, yang dilakukan oleh orang perseorangan atau badan usaha yang bukan merupakan anak perusahaan atau cabang perusahaan yang dimiliki, dikuasai atau menjadi bagian baik langsung maupun tidak langsung dengan usaha kecil atau besar dengan jumlah kekayaan bersih atau hasil penjualan tahunan sebagaimana diatur dalam undang-undang ini.

Kriteria UMKM menurut jumlah aset dan omset yang dimiliki sesuai dengan UndangUndang No. 20 Tahun 2008 dapat dilihat pada Tabel 1. Masalah yang masih dihadapi oleh UMKM adalah rendahnya produktivitas (Sri Susilo, 2005). Penelitian Situmorang dan Situmorang (2008) mengungkapkan bahwa UMKM di Indonesia memiliki beberapa masalah yang antara lain: (a) kurangnya permodalan; (b) kesulitan dalam pemasaran; (c) struktur organisasi sederhana dengan pembagian kerja yang tidak baku; (d) kualitas manajemen rendah; (e) Sumber Daya Manusia (SDM) terbatas dan kualitasnya rendah; (f) mayoritas tidak memiliki laporan keuangan; (g) aspek legalitas lemah; dan (h) rendahnya kualitas teknologi. Pendampingan UMKM dapat membuat UMKM mampu menghadapi permasalahan yang masih menjadi kendala dalam meningkatkan daya saing.

Tabel 1. Kriteria UMKM berdasarkan jumlah aset dan omset

\begin{tabular}{lcc}
\hline \multirow{2}{*}{ Uraian } & \multicolumn{2}{c}{ Kriteria } \\
\cline { 2 - 3 } & Aset & Omset \\
\hline Usaha mikro & Maksimal 50 juta & Maksimal 300 juta \\
Usaha kecil & Lebih dari 50 juta - 500 juta & Lebih dari 300 juta - 2,5 milyar \\
Usaha menengah & Lebih dari 500 juta - 10 milyar & Lebih dari 2,5 milyar - 50 milyar \\
\hline
\end{tabular}

Sumber : Undang-Undang No. 20 Tahun 2008

Menurut Tambunan (2008), UMKM yang berdaya saing tinggi dicirikan oleh: (1) kecenderungan yang meningkat dari laju pertumbuhan volume produksi, (2) pangsa pasar domestik dan atau pasar ekspor yang selalu meningkat, (3) untuk pasar domestik, tidak hanya melayani pasar lokal saja tetapi juga nasional dan (4) untuk pasar ekspor, tidak hanya melayani di satu negara tetapi juga banyak negara. Upaya untuk meningkatkan daya saing UMKM terutama pada peningkatan kualitas produk dan hal yang terkait dengan produk unggulan UMKM tersebut maka perlu dilakukan pendampingan, pelatihan dan evaluasi keberhasilan kegiatan.

Berdasarkan data BPS (2019) menjelaskan bahwa Kelurahan Jagalan merupakan daerah yang banyak terdapat industri, baik industri kecil, menengah maupun skala rumah tangga. Industri kecil sebanyak 3, industri menengah 38 dan industri rumah tangga sebanyak 116. Sektor industri tersebut didominasi oleh komoditi abon, dendeng, krecek salah satunya adalah UMKM Ksatria. Usaha yang bergerak 
di bidang pengolahan daging sapi ini berawal dari usaha milik keluarga yang dikelola belum secara profesional. Usaha ini didirikan hanya sebatas mengolah daging sapi dari hasil pemotongan yang tidak habis terjual, sehingga jumlah produk abon yang tersedia per hari masih terbatas dan belum stabil.

UMKM Ksatria sebagai mitra yang terlibat merupakan salah satu industri skala rumah tangga yang terkenal di Kelurahan Jagalan. UMKM Ksatria memiliki kemampuan untuk produksi abon sapi sebanyak $20 \mathrm{~kg}$ sampai $30 \mathrm{~kg}$ dalam sehari dan abon ayam $40 \mathrm{~kg}$ sampai $50 \mathrm{~kg}$ dalam sehari. Usaha keluarga yang sudah dimiliki sejak tahun 2007 belum dikelola secara optimal. Seiring dengan berjalannya waktu dan semakin meningkatnya omset yang dikelola maka usaha tersebut mulai melakukan perizinan dan legalitas usaha pada tahun 2017. Dampak era pandemi Covid-19 mengakibatkan UMKM Ksatria mengalami penurunan omset yang membuat usaha ini harus berbenah. Permasalahan yang dihadapi oleh UMKM Ksatria (1) kurang optimalnya pemasaran produk; (2) kurang pahamnya cara membesarkan UMKM, hanya fokus dengan memproduksi barang tanpa memikirkan bagaimana strategi bisnis kedepannya lebih besar lagi; (3) kurangnya inovasi produk yang dihasilkan UMKM; (4) kemasan produk terlalu sederhana; (5) masih gagap teknologi.

Berdasarkan latar belakang dan analisis situasi tersebut, maka kegiatan tentang pelatihan dan pendampingan bagi pelaku UMKM Ksatria merupakan hal yang membawa dampak positif dalam ikut memberdayakan UMKM percontohan di Kelurahan Jagalan, Kecamatan Jebres, Surakarta. Kegiatan terutama meningkatnya pengetahuan, keterampilan dan perbaikan di beberapa aspek diharapkan omset penjualan akan meningkat. Manfaat positif juga diperoleh oleh institusi selaku pendamping UMKM berupa meningkatnya jaringan dengan para pelaku UMKM.

\section{BAHAN DAN METODE}

Kegiatan dilakuan di UMKM Ksatria, Kelurahan Jagalan, Kecamatan Jebres, Surakarta pada bulan Juli - September 2020. UMKM Ksatria merupakan UMKM yang dipilih sebagai percontohan dalam kegiatan ini. Penunjukkan UMKM Ksatria dilakukan dengan dasar pemilihan bahwa UMKM tersebut juga merupakan UMKM yang memiliki eksistensi lebih baik dibanding UMKM lainnya yang sejenis baik di lingkungan sekitar maupun di instansi terkait, memiliki karyawan lebih dari 5 orang yang tidak ada ikatan kekerabatan dan juga mempekerjakan tenaga kerja dari lingkungan sekitarnya.

Metode pelaksanaan kegiatan yang dilakukan yaitu meningkatkan motivasi dan kesadaran pelaku UMKM yang terdiri dari pemilik dan juga karyawan yang terlibat. Setelah motivasi dan kesadaran meningkat maka langkah selanjutnya adalah melakukan pelatihan dan pendampingan tentang perbaikan terkait produk, diversifikasi produk, perizinan dan pemasaran untuk meningkatkan daya saing produk yang dihasilkan. Pelatihan dan pendampingan dijabarkan dalam tahap-tahap sebagai berikut, (1) tahap penjajakan; (2) tahap persiapan, membentuk tim yang akan terlibat. Dalam hal ini melibatkan para dosen dan mahasiswa, menyiapkan instruktur pelatihan, menyiapkan modul pelatihan, menyiapkan sarana dan prasarana pelatihan; (3) tahap pelaksanaan; (4) tahap evaluasi, dilakukan evalauasi kepada pelaku UMKM untuk mengetahui tingkat keberhasilan pada perbaikan yang telah dilakukan.

\section{HASIL DAN PEMBAHASAN}

\section{Profil UMKM Ksatria}

UMKM Ksatria adalah salah satu UMKM yang berlokasi di Kelurahan Jagalan, Kecamatan Jebres, Surakarta dengan pemilik atas nama Tri Rahayu, jenis usaha pengolahan daging sapi (Gambar 1). Usaha perseorangan yang awalnya dikelola hanya terbatas pada lingkup keluarga kini semakin berkembang. Menurut kriteria UMKM berdasarkan kepemilikan aset dan omset (Tabel 1) maka UMKM Ksatria tergolong dalam usaha mikro karena modal awal usaha Rp. 50.000.000,00 (lima puluh juta rupiah). Penambahan jumlah karyawan dengan sistem pekerja lepas menunjukkan bahwa UMKM ini masih dalam tahap berkembang.

Produk unggulan UMKM Ksatria adalah abon. Abon produksi UMKM Ksatria telah banyak dikenal karena memiliki rasa yang khas dibanding abon competitor lainnya. Permintaan abon tidak hanya sebagai lauk sumber protein tetapi 
juga dapat dijadikan oleh-oleh khas Solo. Kemampuan produksi abon sapi yang awalnya hanya $5 \mathrm{~kg}$ sampai $8 \mathrm{~kg}$ dan abon ayam $5 \mathrm{~kg}$ sampai $10 \mathrm{~kg}$ semakin tahun semakin meningkat hingga pada akhir tahun 2019 produksi abon UMKM Ksatria sebanyak $20 \mathrm{~kg}$ sampai $30 \mathrm{~kg}$ dalam sehari dan abon ayam $40 \mathrm{~kg}$ sampai $50 \mathrm{~kg}$ dalam sehari.

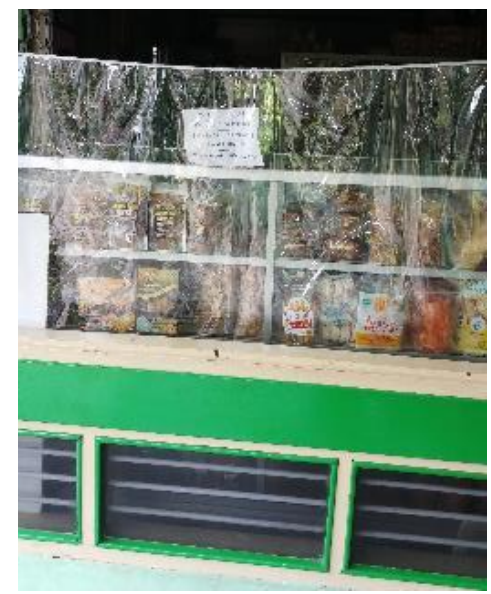

a.
Usaha keluarga yang sudah dimiliki sejak tahun 2007 belum dikelola secara optimal, namun seiring dengan berjalannya waktu dan semakin meningkatnya omset yang dikelola maka usaha tersebut mulai mengurus legalitas izin usaha pada tahun 2017 dan mendapat izin usaha dengan Surat Izin Usaha Mikro dan Kecil No. : 517/84/VI/2017.

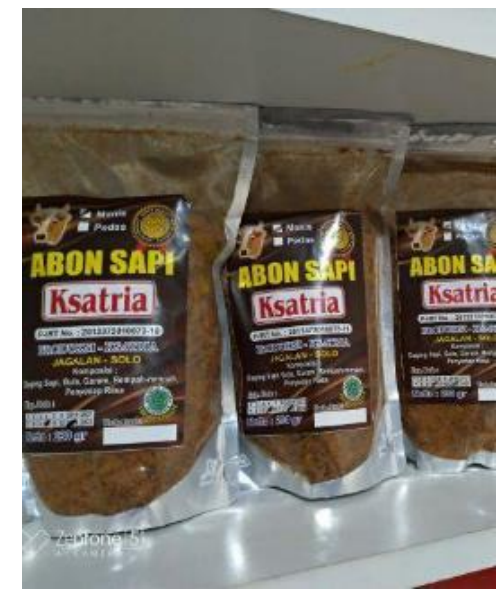

b.

Gambar 1. Lokasi usaha UMKM Ksatria (a) dan produk abon sapi Ksatria (b)

\section{Produk UMKM Ksatria}

Produk UMKM Ksatria antara lain abon (abon sapi dan abon ayam), ayam crispy, srundeng, rambak, dendeng dan kremes. Produk yang dijadikan unggulan UMKM Ksatria adalah produk abon baik abon sapi maupun abon ayam. Abon sapi dan abon ayam yang dijual terdiri dari 3 kemasan yaitu kemasan $500 \mathrm{~g}, 250 \mathrm{~g}$ dan $150 \mathrm{~g}$.

Seiring dengan meningkatnya penjualan sejak tahun 2017-2019 membuat UMKM Ksatria mengganti bentuk kemasan lebih menarik
(Gambar 2). Hal tersebut ditujukan agar konsumen yang belum pernah mencoba dan membeli produk tersebut tertarik terhadap pengemasan yang lebih baik, sedangkan konsumen yang sudah mengetahui kualitas produk juga akan makin menyukai sehingga loyalitas terhadap produk makin meningkat. Semakin banyak pilihan produk membuat konsumen semakin banyak pula pilihan dan memperbesar kemungkinan terjadinya transaksi pembelian produk.

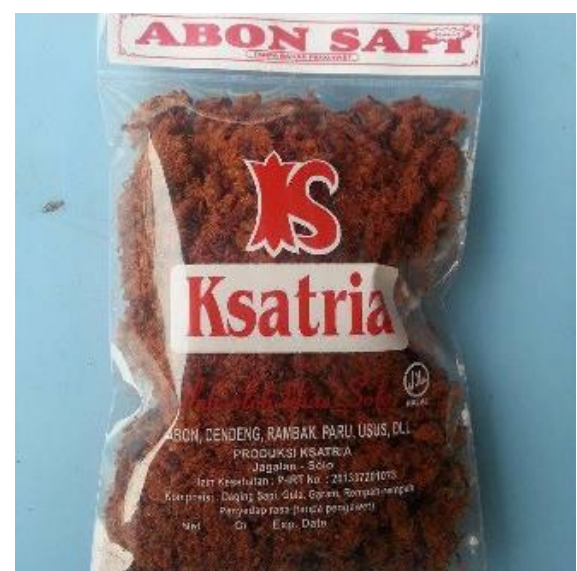

a

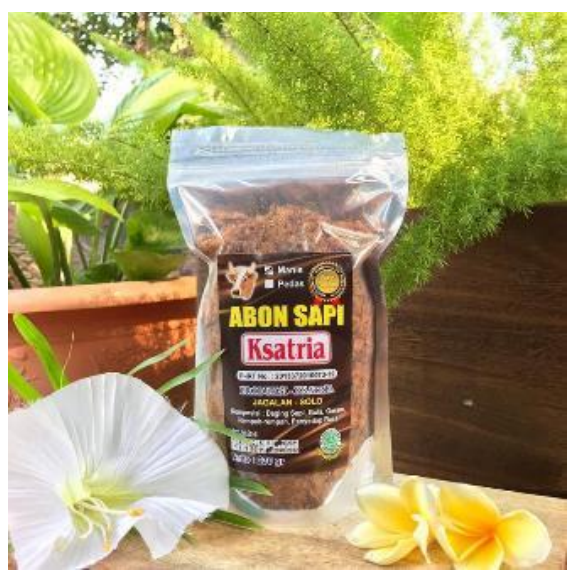

b.

Gambar 2. Perbaikan desain kemasan produk abon UMKM Ksatria lama (a) dan baru (b) 
Pilihan produk adalah kumpulan semua produk dan barang yang ditawarkan untuk dijual dan terdiri dari berbagai lini produk. Kualitas menjadi salah satu penilaian dalam pengendalian kualitas produk abon. Hal ini dilakukan untuk terus menjaga kualitas abon. Pengawasan kualitas dilakukan dengan tujuan menjaga kualitas produk yang dihasilkan dan membayar kepercayaan konsumen sebagai salah satu syarat dalam melakukan pemasaran yang baik. Kemasan yang baik dan menarik akan menciptakan kenyamanan dan ketertarikan tersendiri bagi para konsumen. Ketertarikan konsumen pada kemasan karena kemasan atau packaging merupakan suatu wadah yang menempati suatu barang agar aman, menarik, mempunyai daya pikat bagi seseorang yang ingin membeli suatu produk. Dapat juga menjadi media komunikasi antara produsen dengan calon konsumen, sehingga di dalam desain kemasan tercantum informasi-informasi yang harus diketahui oleh calon konsumen, agar calon konsumen merasa tidak asing (Mukhtar dan Nurif, 2015).

Kemasan awal yang digunakan adalah kemasan plastik Polyethylene (PE) yang kemudian diganti menjadi Aluminium Foil transparan sehingga konsumen dapat melihat produk lebih jelas. Kemasan lain yaitu dalam bentuk toples dengan pemberian label yang berisi informasi mengenai jenis produk, sertifikasi yang didapatkan serta alamat produksi. Jenis abon yang ditawarkan adalah abon sapi dan abon ayam dalam dua varian rasa yaitu manis dan pedas.

\section{Harga}

Harga adalah satu-satunya elemen yang menghasilkan pendapatan dengan memiliki banyak bentuk dan melaksanakan banyak fungsi. Harga abon yang ditawarkan beragam berdasarkan berat abon per kemasan, jenis abon dan cara penyajiannya. Kotler dan Keller (2008) menjelaskan suatu unit bisnis umumnya tidak hanya menetapkan satu harga pada produknya. Oleh karena itu, beberapa cara penyesuaian harga yang dapat dilakukan adalah penetapan harga secara geografis, potongan dan insentif harga, penetapan harga promosi. Penyesuaian harga dilakukan dengan potongan harga dan insentif harga, dimana konsumen akan diberikan potongan untuk jumlah pembelian tertentu.

\section{Promosi}

Kegiatan promosi berkaitan dengan komunikasi pemasaran dimana organisasi berusaha menginformasikan, membujuk dan mengingatkan konsumen secara langsung maupun tidak langsung tentang produk yang dijual. Kotler dan Keller (2008) mejelaskan bahwa komunikasi pemasaran meliputi iklan, promosi penjualan, acara dan pengalaman hubungan masyarakat dan publisitas, pemasaran langsung, pemasaran interaktif, pemasaran dari mulut ke mulut, serta melalui media. UMKM Ksatria melakukan promosi secara konvensional hingga memberikan potongan dan insentif harga, penetapan harga promosi, penjualan online berupa gratis ongkos kirim, atau insentif ongkos kirim.

\section{Distribusi}

UMKM Ksataria adalah salah satu UMKM yang berlokasi di Jagalan RT 01/RW 12, Kelurahan Jagalan, Kecamatan Jebres, Kota Surakarta, menjual produknya dengan menata abon di dalam etalase dan disusun dengan rapi, dengan memperhatikan kebersihan serta memperhatikan kenyamanan konsumen, hal tersebut karena banyaknya konsumen dan tamu yang datang mengunjungi rumah produksi dan untuk menjadikan UMKM Ksatria menjaga kualitas produk. Pendistribusian dilakukan secara konvensional dengan mengantarkan langsung ke konsumen sedangkan distribusi pada pembelian online menggunakan jasa kurir atau jasa kirim rekanan. Selain pendistribusian secara konvensional, UMKM Ksatria juga melakukan pendistribusian secara online menggunakan e-commerce aplikasi seperti Shopee dan Gojek (gofood) (Gambar 3).

\section{Peningkatan keterampilan dan eksistensi UMKM Ksatria}

Peningkatan keterampilan juga sangat mendukung dalam kegiatan pemasaran. Peningkatan keterampilan dapat diperoleh melalui kegiatan pelatihan dan indikator peningkatan berupa perubahan setelah pelatihan. Peningkatan eksistensi UMKM dapat dilihat dengan frekuensi dilibatkannya UMKM pada kegiatan perekonomian baik yang diadakan swasta maupun pemerintah di wilayah tersebut (Gambar 4). 


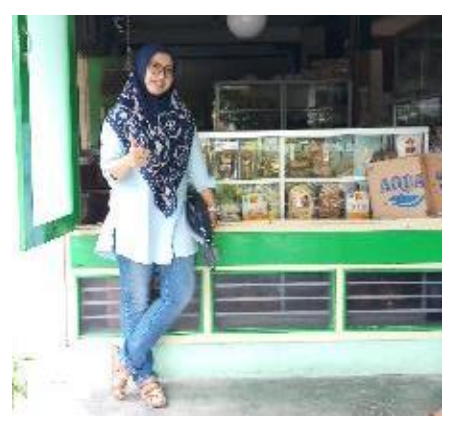

a.

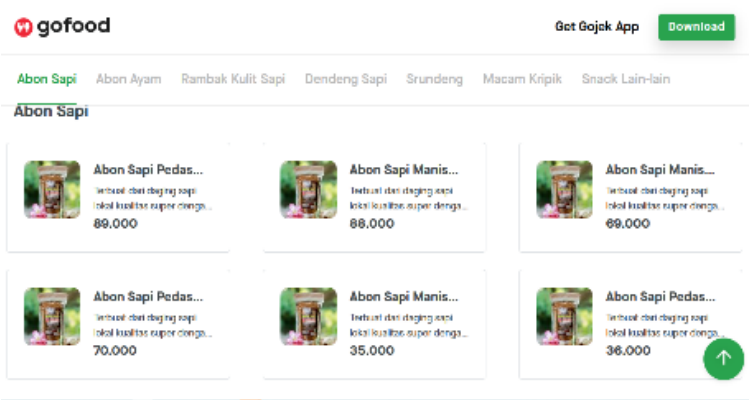

b.

Gambar 3. Pendistribusian produk UMKM Ksatria secara konvensional (a) dan online gofood (b)

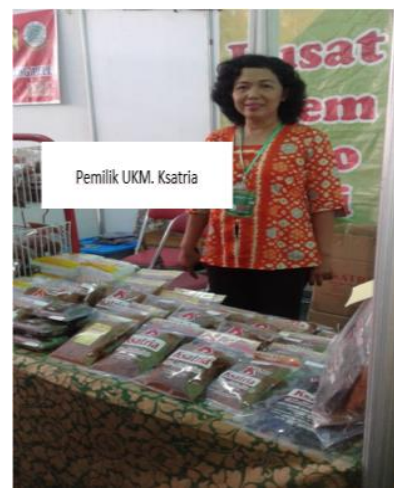

a.

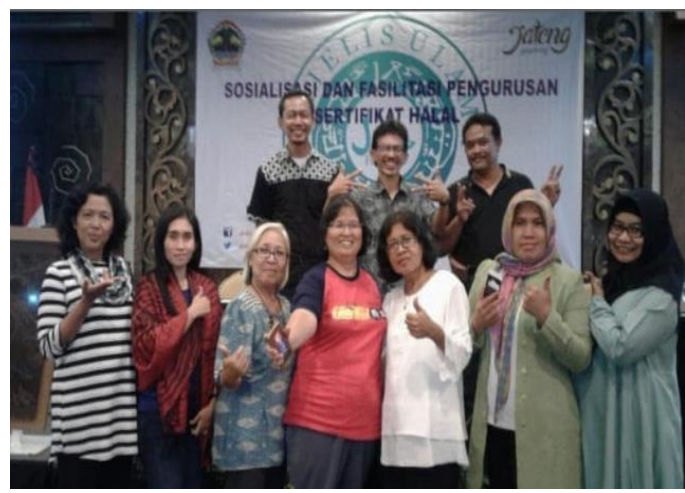

b.

Gambar 4. Pelatihan dan sosialisasi yang diikuti oleh pemilik UMKM Ksatria (a) dan tim (b)

Peningkatan keterampilan melalui beberapa kegiatan pelatihan antara lain kegiatan perbaikan kemasan. Kegiatan perbaikan kemasan membuat mitra melakukan perbaikan jenis dan bahan kemasan (Gambar 2) dan juga meningkatnya kesadaran untuk melakukan perpanjangan izin Produksi Industri Rumah Tangga (P-IRT) dan halal pada kemasan. UMKM Ksatria memiliki P-IRT dan sertifikasi halal dengan No. register

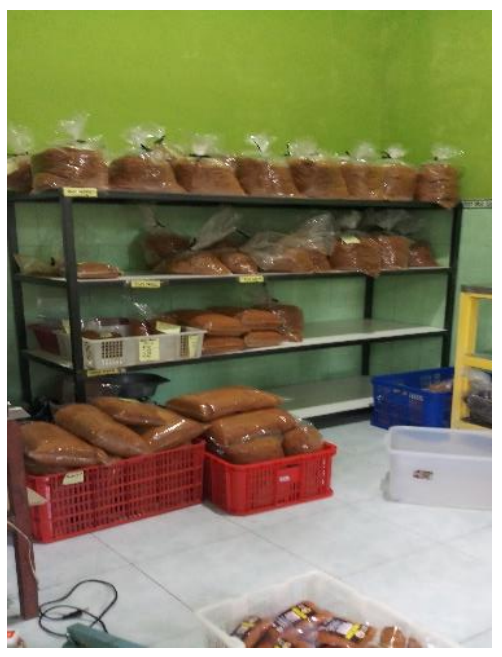

a.
15010030390518 yang dicantumkan pada kemasan.

Dampak peningkatan keterampilan setelah mengikuti pelatihan bidang pemasaran adalah mitra dapat memperluas jaringan pemasaran (Gambar 3) dan dapat memanfaatkan teknologi untuk melakukan pemasaran secara online sehingga mitra dapat meningkatkan penjualan (Gambar 5).

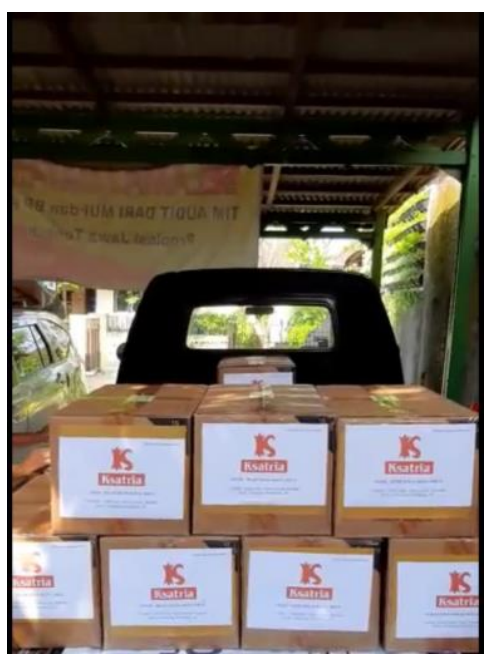

b.

Gambar 5. Peningkatan kapasitas penjualan baik konvensional (a) maupun secara online (b) 
Indikator keberhasilan kegiatan dapat dilihat secara langsung dan tidak langsung, baik secara kualitatif maupun kuantitatif. Indikator keberhasilan dapat diukur dari jumlah warga yang mengikuti kegiatan, frekuensi kehadiran, tingkat kemudahan dalam penyelenggaraan, peningkatan kapasitas peserta kegiatan, peningkatan respon dan kepedulian (Mardikanto dan Poerwoko, 2012). Berdasarkan indikator kemajuan tersebut diharapkan dapat membawa dampat positif bagi masyarakat sebagai pengguna (Swastike et al., 2020).

Peningkatan keterampilan juga membuat UMKM dapat meningkatkan pengetahuan SDM mengenai informasi teknologi terbaru dan dapat dengan cepat melakukan adaptasi. Hal tersebut juga membuat UMKM dapat terhindar dari gagap teknologi yang menjadi salah satu penghambat dalam meningkatkan daya saing.

\section{KESIMPULAN}

Program kegiatan pengabdian kepada UMKM Ksatria telah mencapai hasil yang memuaskan. Hal ini dapat dilihat dari capaian yang telah diperoleh sehingga mitra dapat menghasilkan produk yang mempunyai daya saing di pasaran. Saran untuk kegiatan ini adalah kegiatan pendampingan perlu dilakukan secara berkesinambungan dan evaluasi perkembangan secara periodik.

\section{UCAPAN TERIMA KASIH}

Penulis mengucapkan terima kasih kepada penyandang dana kegiatan PNBP UNS TA. 2020 dengan nomor kontrak 453/UN.27.21/ PN/2020 sehingga kegiatan ini dapat terselenggara. Penulis juga mengapresiasi kepada UMKM Ksatria, tim pelaksana kegiatan dan berbagai pihak yang tidak dapat kami sebutkan satu persatu sehingga kegiatan ini dapat berjalan dengan baik.

\section{DAFTAR PUSTAKA}

BPS - Badan Pusat Statistik. (2019). Tabel perkembangan UMKM pada periode 1997 2013. Tersedia dari https://www.bps.go.id/ statictable/2014/01/30/1322/tabel-perkemban gan-umkm-pada-periode-1997--2013.html

Bank Dunia. (2005). Mendukung usaha kecil dan menengah, Policy Brief. Diakses dari http://www.worldbank.or.id

Kotler, P., \& Keller, K. L. (2008). Marketing management: The millenium edition. Upper SaddleRiver, NJ: Prentice-Hall.

Mardikanto, T., \& Poerwoko, S. (2012). Pemberdayaan masyarakat dalam perspektif kebijakan publik. Bandung: CV Alfabeta.

Mukhtar, S., \& Nurif, M. (2015). Peranan packaging dalam meningkatkan hasil produksi terhadap konsumen. Jurnal Sosial Humaniora, 8(2), 181-191 http://dx.doi.org/10.12962/j244 33527.v8i2.1251

Situmorang, J. W., \& Situmorang, J. (2008). Iklim usaha UKM di era otonomi daerah. INFOKOP , 16, 18-36. Tersedia dari https:// www.yumpu.com/id/document/view/5653997 /iklim-usaha-ukm-di-era-otonomi-daerah-john ny-smecda

Swastike, W., Suryanto, E., Jamhari, \& Sujarwanto, R. O. (2020). Sosialisasi dan peningkatan keterampilan dalam pemanfaatan bahan pengawet alami pada produk nugget di Desa Ngringo, Kecamatan Jaten, Kabupaten Karanganyar. AgriHealth: Journal of Agrifood, Nutrition and Public Health, 1(1), 3038. http://dx.doi.org/10.20961/agrihealth.v1i1 .40935

Sri Susilo, Y. (2005). Strategi survival usaha mikro kecil (Studi empiris pedagang warung angkringan di Yogyakarta. Telaah Bisnis, 6(2), 161-178. Tersedia dari https://scholar.google. com/scholar?cluster $=411414143642614600 \&$ $\mathrm{hl}=$ en\&oi=scholarr

Tambunan, T. (2008). Ukuran daya saing koperasi dan UMKM, background study, RPJM nasional tahun 2010-2014 bidang pemberdayaan Koperasi dan UKM Bappenas

Undang-Undang Nomor 20 Tahun 2008. Usaha Mikro, Kecil, dan Menengah. Tersedia dari https://peraturan.bpk.go.id/Home/Details/396 53/uu-no-20-tahun-2008 